\title{
Literasi Matematis Siswa SMP dalam Menyelesaikan Masalah Kontekstual Ditinjau dari Adversity Quotient (AQ)
}

\author{
Alex B. Mena', Agung Lukito², Tatag Yuli Eko Siswono2² \\ 'SMP Kristen ENSA, Sulawesi Tengah \\ ${ }^{2}$ Pendidikan Matematika Universitas Negeri Surabaya \\ Email: alexbetrand.mena85@gmail.com \\ DOI: http://dx.doi.org/10.15294/kreano.v7i2.6756
}

Rec eived: August, 2016; Accepted: November, 2016; Published: Dec ember, 2016

\begin{abstract}
Abstrak
Tujuan penelitian ini yaitu; (1) mendeskripsikan literasi matematis siswa SMP kategori climber dalam menyelesaikan masalah kontekstual, (2) mendeskripsikan literasi matematis siswa SMP kategori camper dalam menyelesaikan masalah kontekstual, dan (3) mendeskripsikan literasi matematis siswa SMP kategori quitter dalam menyelesaikan masalah kontekstual. Penelitian ini adalah penelitian deskriptif dengan pendekatan kualitatif dengan subjek penelitian tiga orang siswa kelas IX SMP GKST Ensa. Penentuan calon subjek dilakukan dengan memperhatikan rata-rata nilai tugas dan nilai ulangan harian dan jenis kelamin. Selanjutnya calon subjek diberi ARP (Adversity Response Profile) untuk menentukan subjek penelitian dengan kategori climber, camper, dan quitter. Penelitian ini menggunakan instrumen Angket ARP dan Tugas Pemecahan Masalah (TPM). Literasi matematis subjek penelitian diidentifikasi dengan indikator pada 3 (tiga) proses matematika yaitu formulate (merumuskan), employ (menerapkan) dan interpret. Data hasil penelitian akan mendeskripsikan 3 subjek, yaitu subjek climber, subjek camber, dan subjek quitter. Ketiga subjek akan dideskripsikan dalam kegiatan merumuskan (to formulate), menerapkan situasi (to employ), dan menafsirkan (to interpret).
\end{abstract}

\begin{abstract}
Purpose of this research; (1) describe the mathematical literacy school students climber category in solving contextual problems, (2) describe the mathematical literacy school students category camper in solving contextual problems, and (3) describe the mathematical literacy school students category quitter in solving contextual problems. This research is descriptive qualitative approach to the subject of research of three students of class IX SMP GKST Ensa. The selection of candidates subject conducted with respect to the average value of daily tasks and test scores and gender. Further prospective subjects were given ARP (Adversity Response Profile) to determine the subject of research by category climber, camper, and a quitter. This study uses ARP Questionnaire instruments and Troubleshooting Tasks (TPM). Mathematical literacy research subjects identified with the indicator at 3 (three) that formulate mathematical process (formulate), employ (applying) and interpret. Research data will describe three subjects, namely the subject climber, camber subject, and the subject quitter. All three subjects will be described in formulating activities (to formulate), impose a state (to employ), and interpret (to interpret).
\end{abstract}

Keywords : mathematics literacy; contextual problem; adversity quotient

\section{PENDAHULUAN}

Matematika merupakan salah satu sarana berpikir guna menumbuh kembangkan cara berpikir logis, sistematis dan kritis. Matematika sebagai salah satu ilmu dasar, baik aspek terapan maupun aspek penalarannya mendukung guna kemajuan ilmu pengetahuan dan teknologi (Soedjadi, 2000). Oleh karena itu untuk memahami suatu pokok bahasan matematika tentunya siswa terlebih dahulu harus menguasai konsep-konsep matematika. Sehingga dengan begitu siswa dapat lebih memahami suatu pokok bahasan matematika tertentu dan dapat menerapkan untuk menyelesaikan masalah yang sedang dihadapinya.

Fakta di lapangan menunjukkan bahwa pelajaran matematika sangat abstrak dan sangat sulit dipahami. Banyak siswa yang merasa takut dengan pelajaran matematika, siswa merasa cepat bosan dalam belajar mate- 
matika, siswa sering merasa cemas dan takut setiap kali akan mendapat pelajaran matematika karena sudah tertanam dalam benak siswa bahwa matematika itu sulit. Kondisi ini menyebabkan banyak siswa tidak dapat memahami konsep-konsep matematika dengan baik sehingga cenderung memperoleh hasil belajar matematika yang kurang maksimal. Untuk mengatasi kesulitan siswa dalam memahami konsep matematika dengan baik, maka siswa perlu dilatih dengan masalah kontekstual yang berhubungan langsung dengan kehidupan sehari-hari.

Salah satu indikator yang menunjukkan rendahnya literasi matematis siswa Indonesia adalah hasil survei yang dilakukan oleh Programme for International Student Assessment (PISA) yang mengukur kemampuan anak usia 15 tahun dalam literasi membaca, matematika, dan ilmu pengetahuan. Terakhir pada tahun 2012 skor rata-rata Indonesia 375 menempatkan peringkat Indonesia pada posisi 64 dari 65 negara. Indonesia selalu masuk pada peringkat jajaran terbawah klasemen dan juga skor yang diperoleh selalu di bawah rata-rata, jelas ini bukan hasil yang diharapkan (Kelly et al, 2013).

Keterpurukan prestasi Indonesia dalam literasi mtematis semakin terlihat pada survei PISA terbaru tahun 2012 edisi revisi 2014 dimana sebagian besar siswa Indonesia berada di bawah level 1 sebesar $42,3 \%$, pada level 1 sebesar $33,4 \%$, level 2 sebesar $16,8 \%$, level 3 sebesar $5,7 \%$, level 4 sebesar $1,5 \%$, level 5 sebesar $0,3 \%$ dan pada level 6 sebesar $0 \%$ (OECD, 2014).

Hasil di atas juga menunjukkan lemahnya kemampuan penyelesaian masalah siswa Indonesia dalam menyelesaikan masalah kontekstual. Hal ini bisa disebabkan karena soal-soal yang diajarkan guru di sekolah sedikit atau kurang memberikan keterampilan pemecahan masalah sehingga siswa kurang terbiasa menyelesaikan soal pemecahan masalah. Sedangkan soal PISA menuntut kemampuan dalam merumuskan, menerapkan dan menafsirkan masalah matematika dalam berbagai situasi.

Masalah kontekstual yang dimaksud adalah masalah yang isinya atau materinya terkait dengan kehidupan sehari-hari dan ada disekitar lingkungan siswa. (Hadi, 2005). Di lain pihak ada juga siswa yang sangat kesulitan dalam menyelesaikan setiap tantangan hidup yang dihadapi sehingga Adversity Quotient $(\mathrm{AQ})$ dianggap memiliki peran dalam kemampuan penyelesaian masalah kontekstual yang berkaitan dengan dengan literasi matematis.

Berdasarkan latar belakang di atas maka penulis merasa tertarik untuk melakukan penelitian tentang literasi matematis siswa SMP dalam menyelesaikan masalah kontekstual ditinjau dari Adversity Quotient (AQ). Penelitian ini fokus pada siswa yang berusia antara 15 tahun 3 bulan sampai 16 tahun 2 bulan (OECD, 2014:22), dan belum pernah diberikan tes penyelesaian masalah kontekstual untuk mengetahui sejauh mana literasi matematis siswa dan belum pernah menjadi sujek penelitian berkaitan dengan literasi matematis ditinjau dari AO.

"Literacy for All," merupakan slogan yang dikumandangkan oleh United Nations Educational, Scientific, and Cultural Organization (UNESCO), sebuah organisasi internasional yang bergerak di bidang pendidikan. Slogan ini menegaskan hak setiap manusia untuk menjadi "literate" sebagai modal untuk menyongsong kehidupan. Literasi membuat individu, keluarga, dan masyarakat berdaya untuk meningkatkan kualitas hidup mereka. Lebih jauh, literasi memiliki multiplier effect, yakni memberantas kemiskinan, mengurangi angka kematian anak, mengekang pertumbuhan penduduk, mencapai kesetaraan gender dan menjamin pembangunan berkelanjutan, perdamaian, dan demokrasi (UNESCO, 2015). Ojose (2011) menyatakan bahwa: "Mathematics literacy is the knowledge to know and apply basic mathematics in our every day living". Literasi matematis merupakan pengetahuan untuk mengetahui dan menerapkan matematika dasar dalam kehidupan seharihari. Selanjutnya "Mathematical literacy is an individual's capacity to formulate, employ, and interpret mathematics in a variety of contexts. It includes reasoning mathematically and using mathematical concepts, procedures, facts and tools to describe, explain and predict phenomena. It assists individuals to recognise the role that mathematics plays in the world and to 
make the well-founded judgments and decisions needed by constructive, engaged and reflective citizens" (OECD, 2014).

Terdapat tiga aspek yang saling berhubungan berdasarkan definisi literasi matematis PISA 2012 yaitu proses matematika, konten dan konteks (OECD, 2013a), yaitu: (1) Proses Matematika. Proses matematika menggambarkan apa yang dilakukan seseorang untuk menghubungkan konteks masalah dengan matematika dan selanjutnya memecahkan masalah, dan kemampuan yang mendasari proses-proses tersebut. "Formulate', 'employ' and 'interpret', provide a useful and meaningful structure for organising the mathematical processes that describe what individuals do to connect the context of a problem with the mathematics and thus solve the problem (OECD, 2013a:28). Formulate (merumuskan) dalam definisi literasi matematika mengacu kepada kemampuan seseorang dapat mengenali dan mengidentifikasi dalam menggunakan dan kemudian memberikan stuktur matematik pada masalah kontekstual.

Employing (menerapkan) pada literasi matematika yaitu seseorang mampu menerapkan konsep-konsep matematika, fakta, prosedur, dan penalaran matematis untuk memecahkan masalah matematika sehingga mendapatkan kesimpulan matematis. Interpret (menafsirkan) dalam literasi matematika fokus pada kemampuan individu untuk merefleksikan solusi matematika, hasil yang didapatkan atau kesimpulannya dan menafsir- kannya ke dalam konteks nyata kehidupan sehari-hari. (2) Konten Matematika. Komponen konten dalam studi PISA dimaknai sebagai isi atau materi atau subjek matematika yang dipelajari di sekolah yaitu meliputi perubahan dan hubungan (change and relationship), ruang dan bentuk (space and shape), kuantitas (quantity), dan ketidakpastian dan data (uncertainty and data); dan (3) Konteks Matematika. Komponen konteks dalam studi PISA dimaknai sebagai situasi yang tergambar dalam suatu permasalahan yang diujikan yang dapat terdiri atas konteks pribadi (personal), konteks pekerjaan (occupational), konteks masyarakat (social) dan konteks ilmiah (scientific).

Siswono (2008) mendefinisikan bahwa menyelesaikan masalah adalah suatu proses atau upaya individu untuk merespons atau mengatasi halangan atau kendala ketika suatu jawaban atau metode jawaban belum tampak jelas. Nelissen (1999) mendefinisikan konteks sebagai situasi yang menarik perhatian anak dan yang mereka dapat kenali dengan baik.

Soal kontekstual matematika adalah merupakan soal-soal matematika yang menggunakan berbagai konteks sehingga menghadirkan situasi yang pernah dialami secara real bagi anak (Zulkardi dan Ilma, 2006). Selanjutnya Soedjadi (2007) mengatakan bahwa masalah kontekstual adalah masalah yang menggunakan atau memanfaatkan lingkungan yang dekat dengan kehidupan

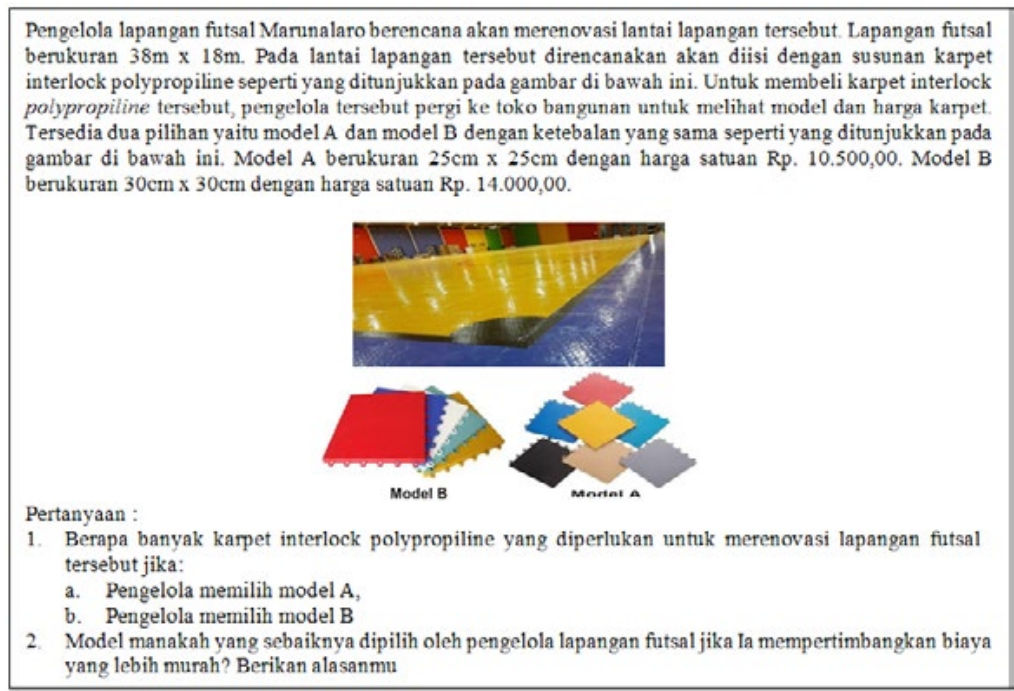

Gambar 1. Contoh Soal Kontekstual yang digunakan dalam penelitian 
anak didik. Contoh masalah kontekstual yang dikembangkan dalam penelitian ini dapat dilihat pada Gambar 1.

Bermain Futsal adalah salah satu permainan sepakbola indoor yang hampir semua orang pernah bermain bahkan menonton di media televisi. Soal di atas termasuk dalam kategori konten quantity (bilangan) dan konteks personal (pribadi) dengan prediksi soal pada level 4 .

Phoolka dan Kaur (2012) berpendapat bahwa " $A Q$ can be useful to predict performance, motivation, empowerment, creativity, productivity, learning, energy, hope, happiness, vitality, emotional health, physical health, persistence, resilience, attitude, longevity and response to change". AO dapat berguna untuk memprediksi kinerja, motivasi, pemberdayaan, kreativitas, produktivitas, pembelajaran, energi, harapan, kebahagiaan, vitalitas, kesehatan emosional, kesehatan fisik, ketekunan, ketahanan, sikap, umur panjang dan respon terhadap perubahan.

$\mathrm{AO}$ adalah kecerdasan mengatasi masalah (daya juang), yaitu kecerdasan seseorang dalam menghadapi kesulitan yang menghadangnya (Stolz, 2005). Senada dengan itu, juga ada beberapa istilah lain yang sering digunakan, misalnya $A Q$ adalah kecerdasan ketangguhan (Efendi, 2005). Nggermanto (2008) menyatakan bahwa kesuksesan belajar dan kerja anda dalam hidup sebagian besar ditentukan oleh $\mathrm{AO}$ anda.

Stolz (2005) menjelaskan ada tiga kategori $A Q$, yaitu kategori quitter ( $A Q$ rendah), camper ( $\mathrm{AQ}$ sedang), dan climber ( $\mathrm{AO}$ tinggi).

Adapun penelitian ini ditujukan untuk: (1) Untuk mendeskripsikan literasi matematis siswa SMP kategori climber dalam menyelesaikan masalah kontekstual; (2) Untuk mendeskripsikan literasi matematis siswa SMP kategori camper dalam menyelesaikan masalah kontekstual; dan (3) Untuk mendeskripsikan literasi matematis siswa SMP kategori quitter dalam menyelesaikan masalah kontekstual.

\section{METODE}

Penelitian ini adalah penelitian deskriptif dengan pendekatan kualitatif dengan subjek penelitian tiga orang siswa kelas IX SMP GKST Ensa. Penentuan calon subjek dilakukan den- gan memperhatikan rata-rata nilai tugas dan nilai ulangan harian dan jenis kelamin. Selanjutnya calon subjek diberi ARP (Adversity Response Profile) untuk menentukan subjek penelitian dengan kategori climber, camper, dan quitter. Penelitian ini menggunakan instrumen Angket ARP dan Tugas Pemecahan Masalah (TPM). Literasi matematis subjek penelitian diidentifikasi dengan indikator pada 3 (tiga) proses matematika yaitu formulate (merumuskan), employ (menerapkan) dan interpret (menafsirkan).

\section{HASIL DAN PEMBAHASAN}

\section{Literasi Matematis Subjek Climber Dalam Menyelesaikan Masalah Kontek- stual Merumuskan (Formulate)}

Subjek climber dalam tahap merumuskan (formulate) permasalahan pada soal dengan indikator mengidentifikasi aspek-aspek matematis suatu masalah yang ditempatkan dalam konteks dunia nyata serta mengidentifikasi variabel yang penting antara lain subjek climber mengidentifikasi soal pada Tugas Pemecahan Masalah dengan beberapa cara yaitu (1) menyebutkan informasi-informasi penting yang dapat digunakan untuk mencari jawaban dari soal seperti diagram, diameter, ruang berbentuk lingkaran, ukuran, jarak, dan panjang langkah dengan memberikan penjelasan yang lengkap (2) menceritakan kembali maksud dari soal secara lengkap termasuk apa yang ditanyakan dalam soal dengan sesekali melihat soal, (3) menyatakan bahwa tidak ada informasi yang kurang dari soal dalam menemukan jawaban. Hal ini sesuai dengan hasil penelitian Chanifah (2013) yang mengatakan bahwa subjek climber dapat memahami masalah dan mampu menangkap informasiinformasi yang diberikan pada soal serta dapat menceritakan kembali dengan bahasanya sendiri.

Dalam mengenali struktur matematika (yang meliputi keteraturan, hubungan dan pola) dalam permasalahan atau situasi, subjek climber dapat mengenali hubungan dalam soal pada konten uncertainty and data yaitu berkaitan dengan materi statistika yaitu da- 
lam menggambar grafik atau diagram. Pada soal konten change and relationship, subjek climber mengenali hubungan dalam soal yaitu hubungan antara rata-rata panjang langkah kaki dan jauhnya perjalanan. Pada konten space and shape, subjek climber mengenali hubungan antara pintu yang membagi ruangan dengan ruangan yang berbentuk lingkaran. Selanjutnya pada konten quantity, subjek climber mengenali konsep persegi panjang dan konsep persegi.

Dalam menyederhanakan situasi atau masalah untuk menjadikannya mudah dianalisis secara matematis, subjek climber menyelesaikan soal menggunakan rumus persegi panjang dan persegi, selanjutnya subjek climber menggunakan konsep perbandingan. Hal ini sesuai dengan Stoltz (2005) mengatakan bahwa climber suka sekali akan tantangan, dan mereka adalah pemikir yang selalu memikirkan kemungkinan-kemungkinan.

\section{Menerapkan (Employ)}

Dalam merancang dan menerapkan strategi menemukan solusi matematis, subjek climber menjelaskan rancangan atau langkah-langkah dalam menyelesaikan soal yaitu dengan menuliskan apa yang diketahui dan yang ditanyakan dalam soal, menuliskan rumus yang akan digunakan, mengganti variabel dengan nilai-nilai yang diketahui ke dalam rumus, selanjutnya menerapkan operasi hitung dan konsep perbandingan. Hal ini sejalan dengan pendapat Stoltz (2005) yang mengatakan bahwa climber berbicara tentang apa yang da- pat dikerjakan dan cara mengerjakannya.

Dalam menggunakan teknologi (komputer) untuk membantu menemukan atau memperkirakan solusi, subjek climber lupa cara menggambar diagram batang dengan bantuan aplikasi Microsoft Excell. Hal ini terjadi karena materinya sudah lama diajarkan. Selanjutnya dalam membuat diagram matematika, grafik dan konstruksi matematis dan menyarikan informasi matematikanya, subjek climber dapat menggambarkan diagram batang di lembar kerja.

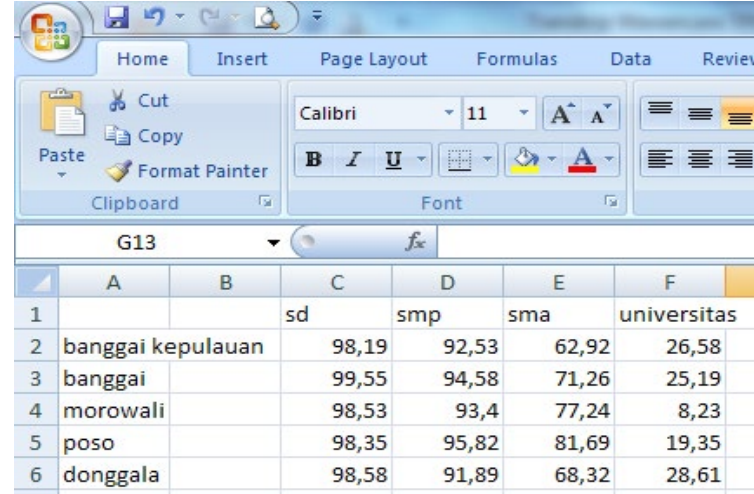

Gambar 2. Hasil kerja subjek climber dengan teknologi

Pada saat menerapkan fakta, aturan, algoritma dan struktur matematis ketika mencari solusi, subjek climber dapat menerapkan setiap langkah penyelesaian yang disebutkan sebelumnya. Subjek climber menerapkan dengan baik aturan dalam persegi dan persegi panjang, perbandingan dan konversi satuan.

Pada konten uncertainty and data, subjek climber menerapkan rumus Sum pada

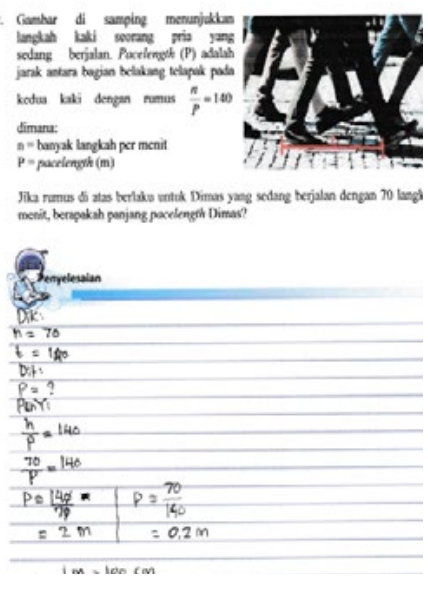

Gambar 3. Hasil kerja subjek climber

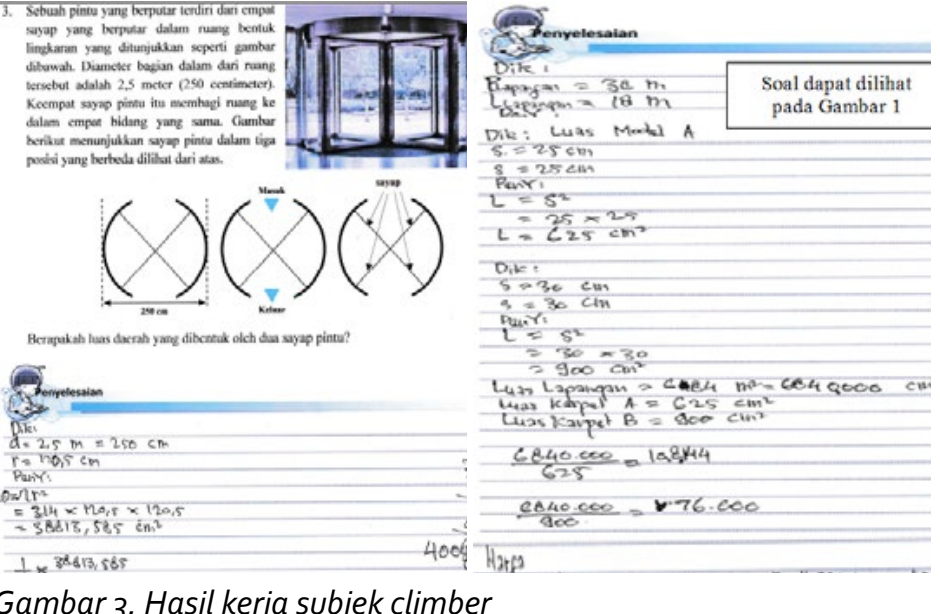

UNNES JOURNALS 
Microsoft Excell dalam menemukan jawaban dari soal, sehingga diperoleh jawaban yang benar. Pada konten change and relationship, subjek climber dapat memanipulasi bentuk dan persamaan aljabar dan representasi geometris sehingga diperoleh jawaban yang benar. Hal ini sejalan dengan Stoltz (2005) yang mengatakan bahwa climber sangat menyukai tantangan dan merupakan pemikir yang memikirkan segala kemungkinan-kemungkinan.

\section{Menafsirkan (Interpret)}

Subjek climber dalam menafsirkan hasil matematis ke dalam konteks dunia nyata konten uncertainty and data, konten change and relationship, konten space and shape dan konten quantity dalam menafsirkan hasil matematis kembali ke dalam konteks dunia nyata melakukan beberapa kegiatan seperti membaca kembali soal dan mengecek hasil perhitungannya. Dalam mengevaluasi kewajaran solusi matematis dalam konteks masalah dunia nyata, subjek climber mengecek hasil yang diperoleh dengan cara mengecek langkah pengerjaan.

Selanjutnya dalam menjelaskan mengapa hasil atau kesimpulan matematis masuk akal atau tidak berdasarkan masalah kontekstual, pada konten uncertainty and data, subjek climber dapat menjelaskan bahwa hasil yang diperoleh masuk akal dilihat dari diagram yang digambar dan hasil menerapkan rumus sum dengan bantuan Microsoft Excell. Subjek climber meyakini bahwa hasil yang diperoleh adalah benar dan masuk akal, dengan memberikan alasan-alasan yang logis. Hal ini sejalan dengan Stoltz (2005) yang menyatakan bahwa climber sering merasa yakin pada sesuatu yang lebih besar daripada diri mereka.

\section{Literasi Matematis Subjek Camper Dalam Menyelesaikan Masalah Kon- tekstual \\ Merumuskan (Formulate)}

Subjek camper dalam merumuskan (formulate) permasalahan pada soal dengan indikator mengidentifikasi aspek-aspek matematis suatu masalah yang ditempatkan dalam konteks dunia nyata serta mengidentifikasi variabel yang penting antara lain subjek camper men- gidentifikasi soal pada Tugas Pemecahan Masalah dengan beberapa cara yaitu (1) menyebutkan informasi-informasi penting yang dapat digunakan untuk mencari jawaban dari soal seperti diagram, diameter, ruang berbentuk lingkaran, ukuran dan jarak (2) menceritakan kembali maksud dari soal dengan menggunakan bahasa sendiri dan sesekali melihat soal, (3) menyatakan bahwa tidak ada informasi yang kurang dari soal dalam menemukan jawaban.

Dalam mengenali struktur matematika (yang meliputi keteraturan, hubungan dan pola) dalam permasalahan atau situasi, subjek camper dapat mengenali hubungan dalam soal pada konten uncertainty and data yaitu berkaitan dengan materi statistika yang telah dipelajari sebelumnya. Pada soal konten change and relationship, subjek camper mengenali hubungan dalam soal yaitu hubungan antara jauhnya perjalanan dan panjang langkah seseorang, pada konten space and shape, subjek camper mengenali hubungan sayap pintu yang membagi ruangan dengan ruangan yang berbentuk lingkaran selanjutnya pada konten quantity, subjek camper mengenali bentuk lantai yang berbentuk persegi panjang dan bentuk karpet yang berbentuk persegi. Hal ini sejalan dengan hasil penelitian Widiastuti (2015) yang mengatakan bahwa subjek camper menyebutkan dan menuliskaan informasi yang ada dalam soal. Hal ini juga sesuai dengan Stoltz (2005) yang menyatakan bahwa camper mau menerima tantangan, meskipun akan "berhenti" atau merasa cukup sampai disitu.

\section{Menerapkan (Employ)}

Subjek camper dalam merumuskan (formulate) indikator merancang dan menerapkan strategi menemukan solusi matematis, subjek camper mengungkapkan langkah dalam menyelesaikan soal yaitu menuliskan apa yang diketahui dan ditanyakan dari soal. Subjek menerapkan fakta, aturan, ketika mencari solusi matematika yang telah dituliskan sebelumnya. Ketika menerapkan fakta dan aturan dalam menemukan jawaban pada konten change and relationship, konten space and shape, dan konten quantity, subjek camper 

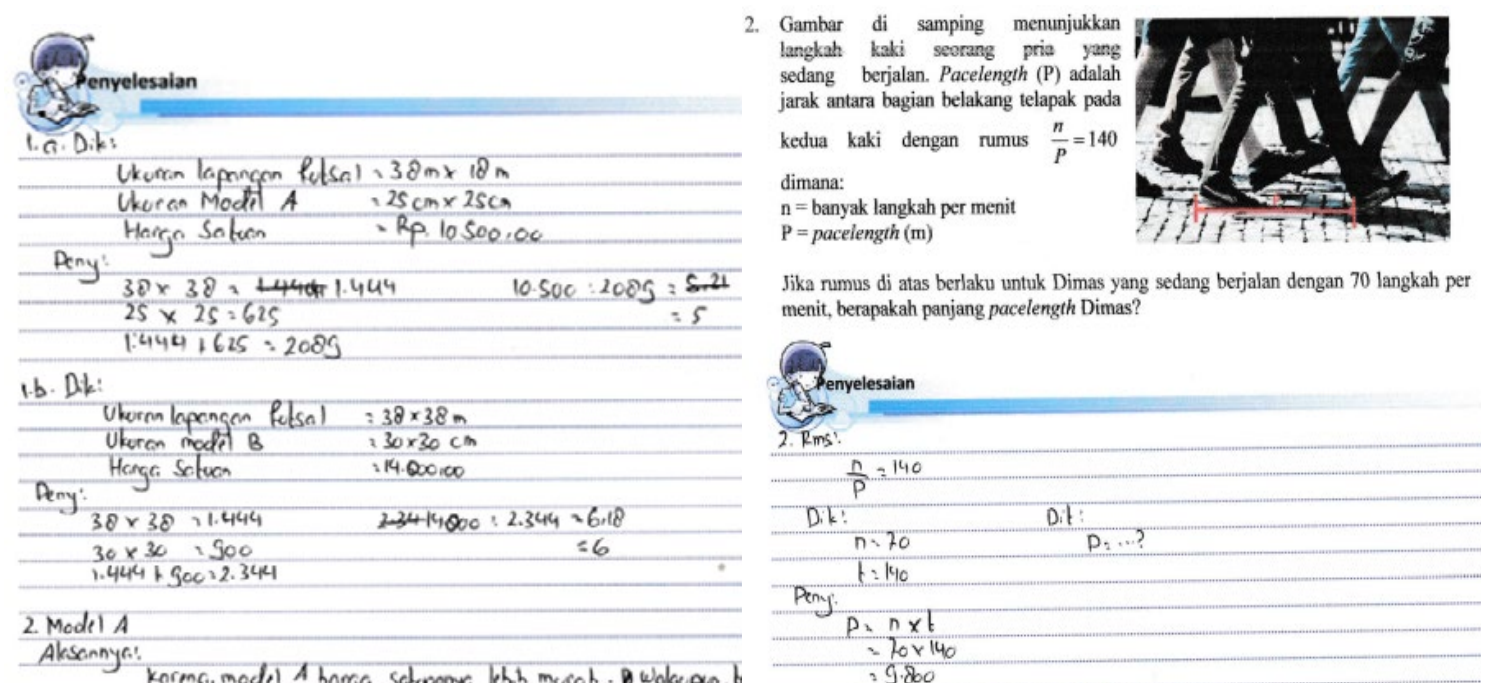

\section{Gambar 4. Hasil kerja subjek camper}

menerapkan apa yang diketahui ke dalam rumus dengan mengganti variabel dengan nilai yang diketahui serta menerapkan operasi hitung. Penyelesaian soal yang dilakukan oleh subjek camper kurang teliti sehingga hasil yang diberikan belum tepat.

Subjek camper tidak dapat menggunakan teknologi sebagai alat bantu untuk menggambar diagram dalam menemukan solusi dengan menggunakan aplikasi Microsoft Excell walaupun data pada tabel telah dituliskan dalam Microsoft Excell. Hal ini terjadi dikarenakan subjek camper lupa bagaimana langkah selanjutnya. Selanjutnya dalam indikator membuat diagram matematika, grafik dan konstruksi matematis dan menyarikan informasi matematikanya, subjek camper menggambar diagram batang masing-masing kabupaten di lembar kerja yang tersedia. Hal ini sesuai dengan teori yang diungkapkan oleh Stoltz (2005) yang mengatakan bahwa camper masih memiliki sejumlah inisiatif, sedikit semangat dan beberapa usaha.

\section{Menafsirkan (Interpret)}

Selanjutnya subjek camper dapat menafsirkan (interpret) konten uncertainty and data, konten change and relationship, konten space and shape dan konten quantity pada indikator menafsirkan hasil matematis kembali ke dalam konteks dunia nyata. Pada konten quantity, subjek camper menuliskan penafsiran dalam bentuk kalimat sedangkan pada 3 konten lain- nya subjek camper tidak menuliskannya.

Subjek camper dalam mengevaluasi kewajaran solusi matematis dalam konteks masalah dunia nyata yaitu pada konten uncertainty and data, subjek camper mengungkapkan bahwa jawaban yang diperoleh sudah benar dengan alasan bahwa kabupaten yang lebih banyak angka partisipasi sekolah penduduk dapat dilihat dari angka yang didapatkan lebih tinggi. Pada konten change and relationship dan konten space and shape, subjek camper mengevaluasi kewajaran solusi dengan cara mengecek perkalian sebelumnya dan hasil yang diperoleh adalah nilai yang dicari.

Selanjutnya subjek camper dalam menjelaskan mengapa hasil atau kesimpulan matematis masuk akal atau tidak berdasarkan masalah kontekstual yaitu subjek camper mengungkapkan pada konten uncertainty and data bahwa jawaban yang diberikan sudah sesuai dengan data pada tabel. Pada konten change and relationship, subjek camper menjelaskan jawabannya masuk akal karena sudah sesuai dengan apa yang ditanyakan dari soal. Pada konten space and shape, subjek camper menjelaskan jawabannya masuk akal dengan mengecek perhitungan yang dilakukan sudah benar. Selanjutnya pada konten quantity, subjek camper menjelaskan bahwa jawabannya masuk akal karena langkah pengerjaanya sudah benar. Dalam menemukan jawaban dari soal, beberapa langkah penyelesaian subjek camper dari keempat konten masih kurang 
teliti, sehingga hasil yang diperoleh belum tepat walaupun menurut subjek camper bahwa jawabannya sudah bernar. Hal ini sejalan dengan Stoltz (2005) yang mengatakan bahwa camper meskipun telah melalui berbagai rintangan, namun mereka akan berhenti juga pada satu tempat dan mereka merasa nyaman disitu. Camper merasa cukup puas telah mencapai suatu tahapan tertentu.

\section{Literasi Matematis Subjek Quitter Dalam Menyelesaikan Masalah Kontekstual Merumuskan (Formulate)}

Subjek quitter dalam merumuskan (formulate) permasalahan pada soal dengan indikator mengidentifikasi aspek-aspek matematis suatu masalah yang ditempatkan dalam konteks dunia nyata serta mengidentifikasi variabel yang penting antara lain subjek quitter mengidentifikasi soal pada Tugas Pemecahan Masalah dengan beberapa cara yaitu (1) menyebutkan informasi-informasi penting yang dapat digunakan untuk mencari jawaban dari soal seperti diagram, diameter, ruang berbentuk lingkaran, ukuran dan jarak (2) menceritakan kembali maksud dari soal dengan menggunakan bahasa sendiri dan sesekali melihat soal, (3) menyatakan bahwa tidak ada informasi yang kurang dari soal dalam menemukan jawaban.
Dalam mengenali struktur matematika (yang meliputi keteraturan, hubungan dan pola) dalam permasalahan atau situasi, subjek quitter dapat mengenali hubungan dalam soal pada konten uncertainty and data seperti diagram batang dan diagram garis dan hubungan model dan harga pada konten space and shape. Pada dua soal konten change and relationship dan konten quantity, subjek tidak dapat mengenali hubungan, keteraturan dan pola dalam permasalahan atau situasi. Jika dikaitkan dengan teori yang diungkapkan Stoltz (2005) untuk tahap merumuskan (formulate) bahwa quitter hanya bekerja secukupnya untuk menyelesaikan masalah maka hal ini bertentangan dengan teori tersebut. Akan tetapi dalam proses wawancara mengidentifikasi masalah, nampak bahwa quitter memberikan jawaban yang kurang antusias. Hal ini sesuai dengan pendapat Stoltz bahwa quitter memiliki karakteristik sikap yang datar.

\section{Menerapkan (Employ)}

Subjek quitter dalam menerapkan (formulate) indikator merancang dan menerapkan strategi menemukan solusi matematis, subjek quitter mengungkapkan langkah dalam menyelesaikan soal yaitu menuliskan apa dan menuliskan rumus yang akan digunakan dalam menemukan jawaban. Subjek menerap-

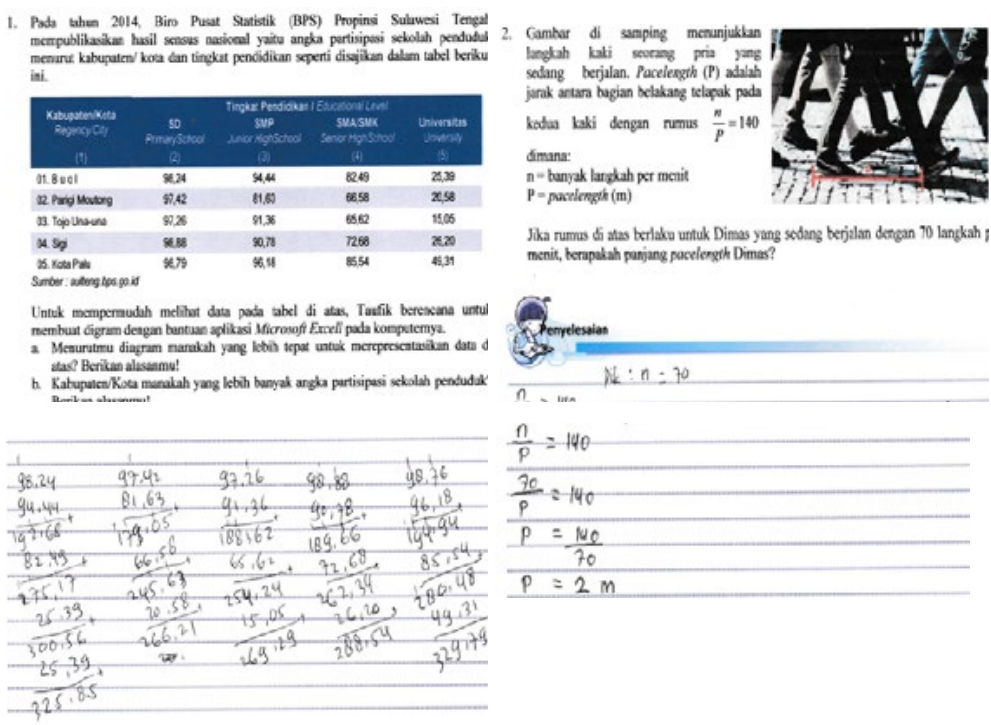

Gambar 5. Hasil kerja subjek quitter

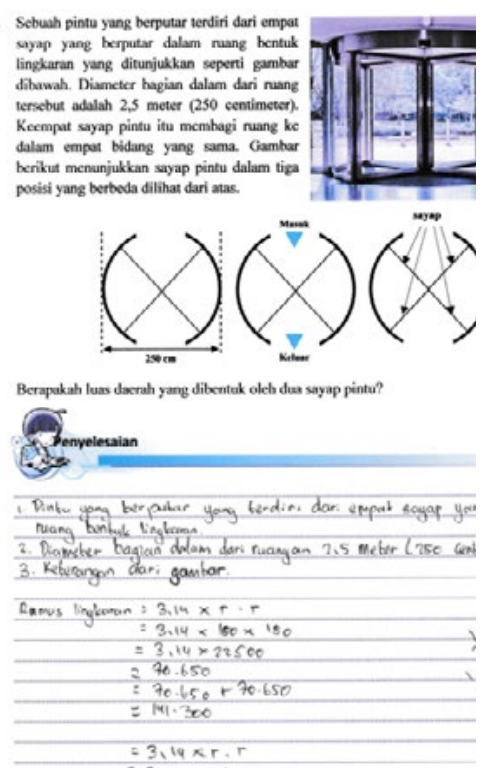


kan fakta, aturan, ketika mencari solusi matematika yang telah disebutkan sebelumnya.

Ketika subjek quitter menerapkan rancangan dalam menemukan jawaban pada konten space and shape dan konten change and relationship, beberapa langkah dalam perhitungan kurang teliti sehingga hasil yang diberikan belum tepat. Pada soal konten uncertainty and data dan konten quantity, subjek quitter tidak dapat menerapkan rancangan yang telah disebutkan, sehingga tidak ada aktivitas dalam menemukan jawaban.

Subjek quitter tidak dapat menggunakan teknologi sebagai alat bantu untuk menggambar diagram dalam menemukan solusi dengan menggunakan aplikasi Microsoft Excell, karena subjek quitter lupa bagaimana cara menggambar. Hal inipun terjadi ketika subjek quitter akan menggambar pada lembar jawaban. Hal ini sesuai dengan teori yang diungkapkan Stoltz (2000), bahwa quitter tidak mau menerima tantangan, dan cenderung menghindari tantangan berat yang muncul dari komitmen yang sesungguhnya. Hal ini juga sejalan dengan penelitian yang dilakukan oleh Chanifah (2013) yang mengatakan bahwa quitter berusaha menjauh dari permasalahan, begitu melihat kesulitan ia akan mundur dan tidak berani menghadapi masalah.

\section{Menafsirkan (Interpret)}

Pada indikator menafsirkan hasil matematis kembali ke dalam konteks dunia nyata, subjek quitter dapat menafsirkan konten change and relationship, space and shape. Pada konten uncertainty and data, subjek quitter menafsirkan hasil matematis hanya melihat data yang ada pada tabel. Penafsiran oleh subjek quitter tidak dituliskan dalam bentuk kata-kata atau kalimat tetapi hanya mengungkapkan apa yang dipikirkan. Sedangkan pada konten quantity, subjek quitter tidak dapat menafsirkan hasil matematis, hal ini disebabkan karena subjek quitter tidak dapat menerapkan rancangan dalam menemukan jawaban.

Subjek quitter dalam mengevaluasi kewajaran solusi matematis dalam konteks masalah dunia nyata, pada konten uncertainty and data subjek quitter hanya melihat berdasarkan perbedaan nilai pada tingkat pendidi- kan. Pada konten change and relationship dan konten space and shape, subjek quitter mengevaluasi kewajaran solusi dengan mengecek kembali langkah-langkah pengerjaan dan hasil perhitungan. Hal ini sesuai dengan penelitian oleh Widiastuti (2015) yang mengemukakan bahwa subjek quitter mengecek kembali dengan menjelaskan secara lisan.

Selanjutnya subjek quitter dalam menjelaskan mengapa hasil atau kesimpulan matematis masuk akal atau tidak berdasarkan masalah kontekstual yaitu subjek quitter mengungkapkan bahwa hasil yang diperoleh sudah masuk akal, tetapi tidak memberikan alasan yang logis mengapa hasil yang diperoleh masuk akal atau tidak. Pada konten quantity, subjek quitter tidak dapat mengevaluasi kewajaran solusi dan tidak dapat menjelaskan mengapa hasil yang diperoleh masuk akal atau tidak dikarenakan subjek quitter tidak dapat menyelesaikan soal. Hal ini sejalan dengan Stoltz (2005) yang mengatakan bahwa quitter bekerja hanya sekedarnya saja.

\section{PENUTUP}

\section{Simpulan}

Literasi Matematis Subjek Climber Dalam Menyelesaikan Masalah Kontekstual

Dalam merumuskan (formulate) permasalahan pada soal subjek climber mengidentifikasi aspek-aspek matematis suatu masalah yang ditempatkan dalam konteks dunia nyata serta mengidentifikasi variabel yang penting, subjek menyebutkan dan menjelaskan informasi-informasi penting dari soal yang dapat digunakan untuk menemukan jawaban secara lengkap. Subjek mengenali struktur matematika (yang meliputi keteraturan, hubungan dan pola) dalam permasalahan atau situasi berkaitan dengan materi yang telah dipelajari sebelumnya. Subjek mengenali konsepkonsep bangun datar dalam menemukan jawaban dari soal dan menyederhanakan situasi atau masalah untuk menjadikannya mudah dianalisis secara matematis.

Dalam menerapkan (employ), subjek climber merancang dan menerapkan strategi menemukan solusi matematis, dengan menuliskan apa yang diketahui dan yang dita- 
nyakan dalam soal, menuliskan rumus yang akan digunakan, mengganti variabel dengan nilai-nilai yang diketahui ke dalam rumus, menerapkan operasi hitung dan konsep yang diketahui sebelumnya. Dalam menggunakan teknologi (komputer) untuk membantu menemukan atau memperkirakan solusi, subjek climber lupa cara menggambar diagram batang dengan bantuan aplikasi Microsoft Excell. Hal ini terjadi karena materinya sudah lama diajarkan. Selanjutnya dalam membuat diagram matematika, grafik dan konstruksi matematis dan menyarikan informasi matematikanya, subjek climber dapat menggambarkan diagram batang di lembar kerja.

Subjek menerapkan fakta, aturan, algoritma dan struktur matematis ketika mencari solusi, subjek climber dapat menerapkan setiap langkah penyelesaian yang disebutkan sebelumnya dengan baik dengan aturan dalam persegi dan persegi panjang, perbandingan dan konversi satuan. Subjek climber dapat memanipulasi bentuk dan persamaan aljabar dan representasi geometris sehingga diperoleh jawaban yang benar.

Dalam menafsirkan (interpret), subjek climber menafsirkan hasil matematis kembali ke dalam konteks dunia nyata dengan membaca kembali soal dan mengecek hasil perhitungannya. Dalam mengevaluasi kewajaran solusi matematis dalam konteks masalah dunia nyata, subjek climber mengecek hasil yang diperoleh dengan cara mengecek langkah pengerjaan. Subjek meyakini bahwa hasil yang diperoleh sudah masuk akal. Subjek dapat menjelaskan mengapa hasil atau kesimpulan matematis masuk akal atau tidak berdasarkan masalah kontekstual dengan alasan-alasan yang logis berdasarkan soal yang diberikan.

\section{Literasi Matematis Subjek Camper Dalam Menyelesaikan Masalah Kontekstual}

Dalam merumuskan (formulate) permasalahan pada soal, subjek quitter mengidentifikasi aspek-aspek matematis suatu masalah yang ditempatkan dalam konteks dunia nyata serta mengidentifikasi variabel yang penting dengan menyebutkan informasi-informasi penting yang dapat digunakan untuk menca- ri jawaban dari soal, kemudian menceritakan kembali maksud dari soal dengan menggunakan bahasa sendiri. Subjek dapat mengenali mengenali struktur matematika (yang meliputi keteraturan, hubungan dan pola) dalam permasalahan atau situasi, berkaitan dengan materi yang telah dipelajari sebelumnya.

Dalam menerapkan (employ), subjek camper merancang dan menerapkan strategi menemukan solusi matematis, menuliskan apa yang diketahui dan ditanyakan dari soal. Subjek menerapkan fakta, aturan, ketika mencari solusi matematika yang telah dituliskan sebelumnya. Subjek menerapkan apa yang diketahui ke dalam rumus dengan mengganti variabel dengan nilai yang diketahui serta menerapkan operasi hitung. Penyelesaian soal yang dilakukan oleh subjek camper kurang teliti sehingga hasil yang diberikan belum tepat.

Subjek camper tidak dapat menggunakan teknologi sebagai alat bantu untuk menggambar diagram dalam menemukan solusi dengan menggunakan aplikasi Microsoft Excell walaupun data pada tabel telah dituliskan dalam Microsoft Excell. Hal ini terjadi dikarenakan subjek camper lupa bagaimana langkah selanjutnya. Subjek dapat membuat diagram matematika, grafik dan konstruksi matematis dan menyarikan informasi matematikanya dengan memberikan penjelasan sesuai dengan gambar yang dibuat.

Dalam menafsirkan (interpret) hasil matematis kembali ke dalam konteks dunia nyata, subjek camper menafsirkan hasil yang diperoleh dengan menuliskan penafsiran dalam bentuk kalimat dan mengungkapkan dengan kata-kata. Subjek mengevaluasi kewajaran solusi matematis dalam konteks masalah dunia nyata yaitu dengan mengecek kembali langkah peenyelesaian soal dan memberikan penjelasan mengenai hasil yang diperoleh.

Subjek meyakini bahwa jawaban yang diperoleh sudah benar. Subjek menjelaskan mengapa hasil atau kesimpulan matematis masuk akal atau tidak berdasarkan masalah kontekstual dengan memberikan alasanalasan mengapa hasil yang diperoleh masuk akal. Subjek meyakini bahwa hasil yang diperoleh sudah benar. 
Literasi Matematis Subjek Quitter Dalam Menyelesaikan Masalah Kontekstual

Dalam merumuskan (formulate) permasalahan, subjek quitter mengidentifikasi aspekaspek matematis suatu masalah yang ditempatkan dalam konteks dunia nyata serta mengidentifikasi variabel penting antara lain subjek quitter mengidentifikasi soal dengan menyebutkan informasi-informasi penting yang dapat digunakan untuk menjawab pertanyaan dalam soal dengan menggunakan bahasa sendiri. Subjek quitter hanya mengenali struktur matematika (yang meliputi keteraturan, hubungan dan pola) dalam permasalahan atau situasi pada konten uncertainty and data (ketidakpastian dan data).

Dalam menerapkan (employ), subjek quitter merancang dan menerapkan strategi menemukan solusi matematis dengan menuliskan minformasi yang diperoleh dari soal dan menuliskan aturan yang akan digunakan dalam menemukan jawaban. Subjek quitter tidak secara lengkap menerapkan fakta dan aturan ketika mencari solusi matematika yang telah disebutkan sebelumnya. Subjek kurang teliti dalam perhitungan sehingga hasil yang diperoleh belum tepat.

Subjek quitter tidak dapat menggunakan teknologi sebagai alat bantu untuk menggambar diagram dan untuk menemukan atau memperkirakan solusi dengan menggunakan aplikasi Microsoft Excell. Subjek quitter tidak dapat menggambar diagram batang pada lembar kerja yang tersedia. Pada konten tertentu, subjek quitter tidak dapat menerapkan apa yang telah diketahui dari soal dan tidak mempunyai usaha untuk menyelesaikan soal.

Dalam menafsirkan (interpret) hasil matematis kembali ke dalam konteks dunia nyata, subjek quitter tidak menafsirkan secara lengkap setiap hasil yang diperoleh. Penafsiran yang diungkapkan tidak dikaitkan dengan konteks dunia nyata. Penafsiran oleh subjek tidak dituliskan dalam bentuk kata-kata atau kalimat tetapi hanya mengungkapkan apa yang dipikirkan. Dalam mengevaluasi kewajaran solusi matematis dalam konteks masalah dunia nyata yaitu dengan cara mengecek kembali langkah-langkah penyelesaian dan hasil perhitungan. Subjek meyakini bahwa hasil yang diperoleh setelah pengecekan adalah hasil yang benar walaupun hasil yang diperoleh kurang tepat.

Dalam menjelaskan mengapa hasil atau kesimpulan masuk akal atau tidak berdasarkan masalah kontekstual, subjek quitter meyakini bahwa hasil yang diperoleh adalah hasil yang masuk akal, tetapi subjek tidak dapat memberikan alasan yang logis mengapa hasil yang diperoleh masuk akal atau tidak.

\section{Saran}

Dari hasil penelitian ini, beberapa saran yang dapat peneliti kemukakan antara lain: (1) Penelitian ini hanya terbatas pada literasi matematis siswa SMP dalam menyelesaikan masalah kontekstual ditinjau dari adversity quotient dengan subjek berjenis kelamin sama dan kemampuan matematika setara. Sehingga untuk literasi matematis siswa dalam menyelesaikan masalah kontekstual dengan subjek berjenis kelamin berbeda (laki-laki dan perempuan) dan kemampuan matematika yang berbeda (tinggi sedang dan rendah) belum diketahui, sehingga memerlukan penelitian lebih lanjut; (2) Perlu penelitian lebih lanjut dengan semua konteks soal dan menggunakan keenam level soal untuk mendapatkan hasil yang lebih mendalam dan melakukan wawancara lebih mendalam. Hal dilakukan agar lebih meyakinkan atau memantapkan hasil penelitian yang dihasilkan.

\section{DAFTAR PUSTAKA}

Chanifah, N. (2013). Profil Pemecahan Masalah Kontekstual Geometri Siswa Smp Berdasarkan Adversity Quotient (Aq). Unpublished Thesis, Universitas Negeri Surabaya.

Efendi, A. (2005). Revolusi Kecerdasan Abad 21: Kritik $\mathrm{MI}, \mathrm{El}, \mathrm{SQ}, \mathrm{AQ}$, dan Successful Intelligence Atas IQ. Bandung: Alfabeta.

Hadi, S. (2005). Pendidikan Matematika Realistik dan Implementasinya. Banjarmasin: Tulip.

Kelly, D., Nord, C. W., Jenkins, F., Chan, J. Y., \& Kastberg, D. (2013). Performance of US 15-Year-Old Students in Mathematics, Science, and Reading Literacy in an International Context. First Look at PISA 2012. NCES 2014-024. National Center for Education Statistics.

Nelissen, J. M. C. (1999). Thinking skills in realistic mathematics. Teaching and learning thinking skills, 189-213. 
Nggermanto, A. (2008). Quantum Quotient (Kecerdasan Kuantum) : Cara Cepat Melejitkan Iq, Eq, Dan Sq Secara Harmonis. Bandung: Penerbit Nuansa.

OECD. (2013a). Pisa 2012 Assessment and Analytical Framework: Mathematics, Reading, Science, Problem Solving and Financial Literacy. Paris: OECD Publishing.

OECD. (2014). Pisa 2012 Results: What Students Know and Can Do (Volume I, Revised Edition, February 2014). Paris: OECD Publishing.

Ojose, B. (2011). Mathematics Literacy: Are We Able To Put The Mathematics We Learn Into Everyday Use?. Journal of Mathematics Education, 4(1), 89100.

Phoolka, E. S., \& Kaur, N. (2012). Adversity Quotient: A new paradigm to explore. Contemporary Business Studies, 3(4), 67-78.

Siswono, T.Y.E. (2008). Model Pembelajaran Matematika Berbasis Pengajaran Dan Pemecahan Masalah Untuk Meningkatkan Kemampuan Berpikir Kreatif. Surabaya: Unesa University Press.

Soedjadi, R. (2000). Kiat Pendidikan Matematika Di In- donesia Konstatasi Keadaan Masa Kini Menuju Harapan Depan. Jakarta: Direktorat Jenderal Pendidikan Tinggi Departemen Pendidikan Nasional.

Soedjadi, R. (2007). Masalah Kontekstual Sebagai Batu Sendi Matematika Sekolah. UNESA Surabaya: Pusat Sains dan Matematika Sekolah.

Stoltz, P.G. (2005). Adversity Quotient: Turning Obstacles into Opportunities (Mengubah Hambatan Menjadi Peluang) (T. Hermaya, Trans. Y. Hardiwati Ed. 6 ed.). Jakarta: PT. Grasindo Indonesia.

UNESCO. (2015). Literacy for All. Retrieved 10 Desember 2015 http://en.unesco.org/themes/literacyall

Widiastuti, T. (2015). Proses Berpikir Siswa Smp Dalam Memecahkan Masalah Matematika Ditinjau Dari Adversity Quotient (Aq). Unpublished Thesis, Universitas Negeri Surabaya.

Zulkardi, \& Ilma, R. (2006). Mendesain Sendiri Soal Kontekstual Matematika. Paper presented at the Konferensi Nasional Matematika (KNM) ke 13, Semarang. 